\title{
Sylvatic foci of the Chagas disease vector Triatoma infestans in Chile: description of a new focus and challenges for control programs
}

\author{
Antonella Bacigalupo', Fernando Torres-Pérez², Verónica Segovia', Alejandro García ${ }^{3}$, \\ Juana P Correa', Lucila Moreno', Patricio Arroyo', Pedro E Cattan¹/+ \\ ${ }^{1}$ Departamento de Ciencias Biológicas Animales, Facultad de Ciencias Veterinarias y Pecuarias ${ }^{3}$ Unidad Docente de Parasitología, \\ Facultad de Medicina Occidente, Universidad de Chile, Casilla 2, Correo 15, Santiago, Chile 2Departments of Pathology and Biology, \\ University of New Mexico, Albuquerque, NM, USA
}

Triatoma infestans is one of the main domestic vectors of Chagas disease. Reports of wild habitat occurrences have recently increased. In Chile, after a successful elimination campaign of T. infestans domestic infestation, a sylvatic focus was reported in bromeliads in the metropolitan region. Here, we report a new focus of sylvatic $\mathrm{T}$. infestans inhabiting rock piles in the Valparaiso region in central Chile. All $\mathrm{T}$. infestans captured were nymphal instars living among the stones, which were inhabited by several mammal species, along with the sylvatic triatomine vector Mepraia spinolai. We found a prevalence of infection with Trypanosoma cruzi of $36.54 \%$ in $\mathrm{T}$. infestans, similar to the previous report for sylvatic specimens from bromeliads. Sylvatic populations of $\mathrm{T}$. infestans should be studied at different geographic scales to elucidate their role in the maintenance of the sylvatic transmission cycle of $\mathrm{T}$. cruzi and their possible role in threatening the domestic elimination of this vector. This information should be used to redesign the control programs in Chile to avoid the re-establishment of the domestic cycle.

Key words: Triatoma infestans - triatominae - Trypanosoma cruzi - Sylvatic Chagas disease vectors

Chagas disease, caused by the protozoan Trypanosoma cruzi and transmitted by triatomine insect vectors, affects about 10 million people worldwide (Schmunis 2000) and is the third most important global parasitic disease after malaria and schistosomiasis (World Bank 1993). Because of effective vector control campaigns, the number of acute cases has decreased markedly and has been reduced to nearly zero in previously highly endemic areas of Uruguay, Chile and Brazil (Schofield et al. 2006).

The Chagas disease vector Triatoma infestans (Klug 1834) was historically considered an exclusively domestic insect, but it has now been reported in sylvan environments (Noireau et al. 2005, Noireau 2009). The first sylvatic population of T. infestans was reported in Cochabamba, Bolivia, inhabiting rock piles associated with wild guinea pigs (Torrico 1946). Other reports have shown T. infestans in Argentina (Mazza \& Schreiber 1938, Mazza 1943, Ceballos et al. 2009), Paraguay (Velasquez \& González 1959) and Brazil (Barretto et al. 1963) under rocks or trunks of fallen trees, in hollow trees, under bark, in shelters or burrows of marsupials and rodents and in bird nests occupied by owls, parrots or small rodents (Noireau et al. 1997). Wild T. infestans has been found in an extended geographical region throughout Chaco and three Andean departments of Bolivia: Cochabamba, La Paz and Potosí (Noireau et al. 1999, 2000, 2002, 2005, Cortez et al. 2007). T. infestans

Financial support: FONDECYT (1070960)

+Corresponding author: pcattan@uchile.cl

Received 29 December 2009

Accepted 27 April 2010 was considered to be eradicable due to its strictly domestic behavior and its non-autochthonous status outside of its apparent centre of origin in the Andean valleys of Bolivia. This theory has been challenged by empirical evidence of wild individuals collected by vector control programs and researchers over several decades (Gürtler 2009). Sylvatic triatomines may occasionally invade human residences, acting as founders of new colonies (Fitzpatrick et al. 2008). Hence, it is necessary to study the ecology and behavior of their populations to understand the domiciliation process and generate new strategies for their control (Beard et al. 2002, Guhl et al. 2009, Moncayo \& Silveira 2009).

In Chile, parasite transmission from vectors to humans occurs mainly in rural and suburban areas encompassing the northern desert and semiarid and Mediterranean environments, between latitudes $18^{\circ} 30^{\prime} \mathrm{S}$ and $34^{\circ} 36^{\prime} \mathrm{S}$. The triatomine insects $T$. infestans, Mepraia spinolai (Porter 1934) and Mepraia gajardoi are the vector species that have been reported in that area (Spinola 1852, Neghme 1982, Lent et al. 1994, Frias et al. 1998).

In 1991, several countries of South America, including Chile, established the Southern Cone Initiative for control of Chagas disease (INCOSUR-Chagas), which provided united strategy, control actions and an information system used to evaluate local control programs (Silveira 2002). The specific aims of the initiative were the following: (i) the elimination of $T$. infestans from dwellings and their surroundings in endemic areas, (ii) the reduction and elimination of domiciliary infestation of other triatomines present in the same areas occupied by $T$. infestans and (iii) the reduction and elimination of transmission by blood transfusion by strict control of blood banks and effective screening of blood donors (Silveira 2002). The implementation of these programs 
in Chile resulted in the elimination of $T$. infestans colonies from domestic spaces, interrupting vectorial transmission to humans in 1999 (Lorca et al. 2001). However, the discovery of a wild location of this species in central Chile, inhabiting of bromeliads of the genus Puya sp. along with sylvatic and synanthropic micro-mammals (Bacigalupo et al. 2006, Galuppo et al. 2009), has brought new challenges to the control of vector populations and, therefore, to the prevention of the transmission of T. cruzi.

We report a new area infested with $T$. infestans in Chile outside human residences whose inhabitants continuously report finding adult individuals inside their dwellings throughout the summer. This locality exhibits different ecological characteristics than those previously described in Chile (Bacigalupo et al. 2006), allowing us to discuss the epidemiological importance of sylvatic populations of T. infestans in Chile and emphasizes that increasing efforts should be devoted to the study of $T$. infestans populations, mainly in control plans of Chagas disease vectors.

\section{MATERIALS AND METHODS}

The study area is an agricultural area located in the locality of Sahondé at the commune of Putaendo in the Valparaíso region of Chile (Fig. 1) near the rural city of Putaendo (32³7’34'S, 7043'00'W; $825 \mathrm{~m}$ ). The climate is subtropical, semi-arid Mediterranean, with a dry season of 7-8 months and a wet winter (mean annual rainfall of $125.7 \mathrm{~mm}$ ) (Novoa et al. 1989). The inspected site was a rural road, with rock piles on both sides, located in a valley (Fig. 2). Native vegetation was composed of

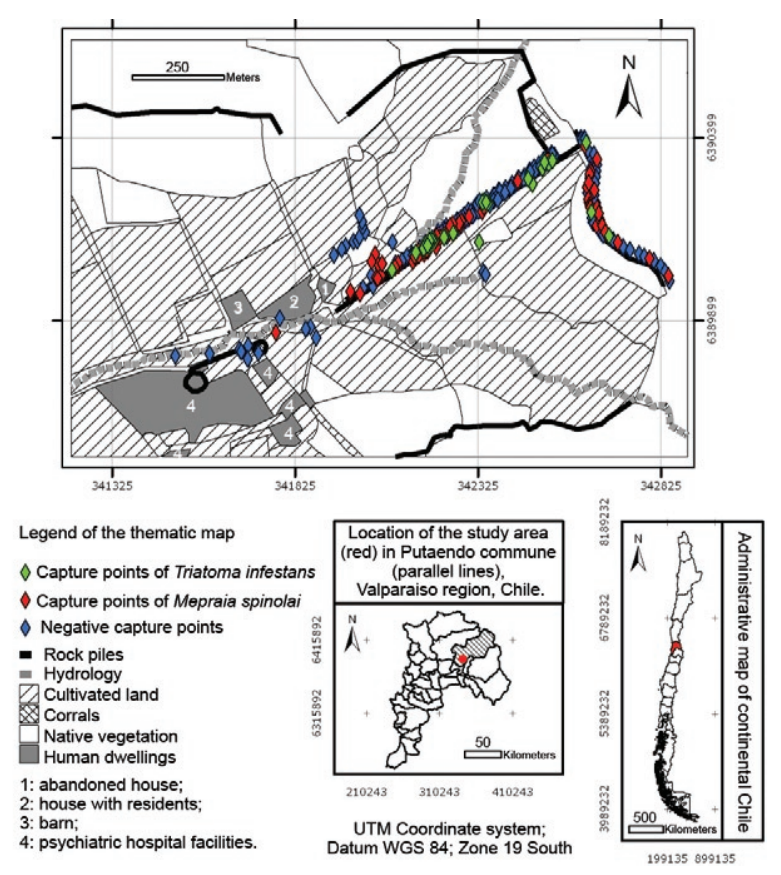

Fig: 1: thematic map of the study area in Sahondé, commune of Putaendo, showing the location of georeferenced points of positive captures of triatomines and negative inspected points, respectively, during 2008 and 2009. Administrative map of Chile and Valparaíso region showing the position of the commune of Putaendo. a spiny open forest of Acacia caven (hawthorn) and Prosopis chilensis (Chilean mesquite) along with the shrubs Proustia cuneifolia, Baccharis linearis and Schinus polygama (Gajardo 1995). Observed animal species in the study area are listed in Table I.

Triatomines were captured using three different sources of carbon dioxide-emitting bait: (i) dry ice (frozen carbon dioxide) (Botto-Mahan et al. 2002), (ii) yeast with water and sugar to induce fermentation (Lorenzo et al. 1998) and (iii) a Mus musculus laboratory mouse (Noireau et al. 1999). All carbon dioxide sources were placed in a plastic device with a wire mesh to separate the bait from the capture section of the device. We sampled for three nights in February and November 2008 and four nights in January and May 2009. We attached an average of 64 baited traps per night to the stones in pairs of two different baits placed approximately $10 \mathrm{~m}$ apart (Fig. 2). Traps were placed before dusk and removed the next morning. Each point was georeferenced using a global positioning system device (GARMIN ${ }^{\mathrm{TM}}$ Etrex Vista Cx). Captured triatomines were placed in individual containers with paper as a substrate and transported to the Laboratory of Ecology of the Faculty of Veterinary Science, University of Chile, where they were taxonomically identified according to Lent and Wygodzinsky (1979) (key for adult specimens), Brewer et al. (1981) (key to distinguish nymphal instars of T. infestans), Lent et al. (1994) (key to Mepraia genus) and Frias et al. (1987) (description of Triatoma spinolai eggs, nymphal instars and adults). Individuals were maintained in a climatic chamber under controlled environmental conditions $\left(27^{\circ} \mathrm{C}\right.$ and $65-70 \%$ relative humidity). They were fed on rabbits (Oryctolagus cuniculus) every month.

A thematic map of the study area was produced with the georeferenced points and administrative maps of the study area were produced with layers in shapefile format (Gisdata Chile) (www.rulamahue.cl/) using ArcGISTM 9.2 (ESRI 1999-2006). The population structure of both species was graphically represented using SigmaPlot ${ }^{\mathrm{TM}}$ 8.02 (SPSS 1986-2001) (sigmaplot.com/products/sigmaplot/produpdates/prod-updates5.php).

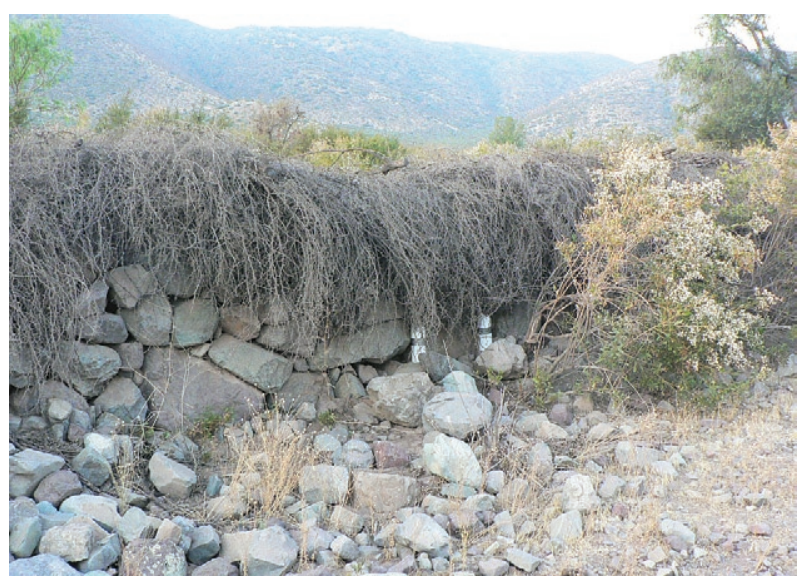

Fig. 2: photograph showing the positioning of baited trap pairs along the rock piles, with the native vegetation surrounding them. 


\section{TABLE I}

List of vertebrate species observed in the study area, located in the locality of Sahondé, commune of Putaendo, Valparaíso region, Chile

\begin{tabular}{|c|c|c|}
\hline Order & Family & Species \\
\hline Didelphimorphia & Didelphidae & Thylamys elegans ${ }^{a}$ \\
\hline \multirow[t]{6}{*}{ Rodentia } & Octodontidae & Octodon degus ${ }^{a}$ \\
\hline & Cricetidae & Phyllotis darwini ${ }^{a}$ \\
\hline & & $\begin{array}{l}\text { Oligoryzomys } \\
\text { longicaudatus }^{a}\end{array}$ \\
\hline & Abrocomidae & Abrocoma bennetti ${ }^{a}$ \\
\hline & Muridae & Rattus rattus ${ }^{b}$ \\
\hline & & Rattus norvegicus ${ }^{b}$ \\
\hline Lagomorpha & Leporidae & Oryctolagus cuniculus ${ }^{a}$ \\
\hline Perissodactyla & Equidae & Equus caballus ${ }^{c}$ \\
\hline \multirow[t]{2}{*}{ Cetartiodactyla } & Bovidae & Capra hircus \\
\hline & & Bos taurus ${ }^{c}$ \\
\hline Carnivora & Canidae & Canis lupus familiaris ${ }^{c}$ \\
\hline Columbiformes & Columbidae & Columba livia ${ }^{b}$ \\
\hline \multirow[t]{3}{*}{ Falconiformes } & Accipitridae & Geranoaetus melanoleucus ${ }^{a}$ \\
\hline & & Parabuteo unicinctus ${ }^{a}$ \\
\hline & Falconidae & Milvago chimango ${ }^{a}$ \\
\hline \multirow[t]{3}{*}{ Passeriformes } & Turdidae & Turdus falklandii magellanicus ${ }^{a}$ \\
\hline & Mimidae & Mimus thenca $a^{a}$ \\
\hline & Fringillidae & Curaeus curaeus curaeus ${ }^{a}$ \\
\hline Galliformes & Odontophoridae & Callipepla californica ${ }^{a}$ \\
\hline Caprimulgiformes & Caprimulgidae & Caprimulgus longirostris bifasciatus ${ }^{a}$ \\
\hline
\end{tabular}

$a$ : wild or sylvatic species; $b$ : synanthropic species; $c$ : domestic species.

A subsample of T. infestans, corresponding to individuals that died spontaneously, was subjected to taxonomic status confirmation using sequencing of a 661-nt fragment of mitochondrial DNA cytochrome oxidase I (F TorresPerez et al., unpublished observations). We performed phylogenetic analyses using the program BEAST (Drummond \& Rambaut 2007), including several triatomines available at GenBank (data not shown). The remaining samples were kept alive for other studies.

The subsample of dead individuals along with spontaneous defecations from live individuals (obtained until April 2009) was analyzed for T. cruzi infection. To determine the status of infection with T. cruzi in $T$. infestans, the abdomens of dead individuals were individually macerated in guanidine-HCl-EDTA and incubated at $56^{\circ} \mathrm{C}$ for $3 \mathrm{~h}$ with proteinase K. Spontaneous defecations from live subjects were diluted in $15 \mu \mathrm{L}$ guanidine-HCl-EDTA and placed in an Eppendorf tube. A total of $200 \mu \mathrm{L}$ of those samples were boiled individually, followed by incubation at $56^{\circ} \mathrm{C}$ with protease for $10 \mathrm{~min}$. The genomic DNA of all samples was extracted using the QIAamp Mini Kit (QIAGENTM) and the product was stored at $-20^{\circ} \mathrm{C}$. Each sample was subjected to polymerase chain reaction (PCR) as follows: $0.5 \mu \mathrm{L}$ of each oligonucleotide 121 (5'-AAA-TAA TGT ACG
GGG GAG ATG CAT GA-3') and 122 (5'-GGT TCG ATT GGG GTT GGT GTA ATA TA-3'), which anneal to the conserved sequence blocks CSB2 and CSB3 of the minicircles, respectively (Wincker et al. 1994), $200 \mathrm{mM}$ Tris-HCl, pH 8.4 and $500 \mathrm{mM} \mathrm{KCl}, 0.2 \mathrm{mM}$ dNTPs, 1.5 $\mathrm{mM} \mathrm{MgCl}, 2.5 \mathrm{U} / \mu \mathrm{L}$ Taq DNA polymerase and doubledistilled water. Each experiment included a negative control of water instead of DNA and a positive control of purified kynetoplastic DNA (kDNA) of T. cruzi. Products obtained from the PCR were run on a $2 \%$ agarose gel and visualized using ethidium bromide staining.

The levels of infection found in this study were compared with those previously reported from specimens of a sylvatic habitat in the metropolitan region (Bacigalupo et al. 2006) using Pearson's Chi-square test. We also examined differences between the levels of infection with T. cruzi of nymphal instars within the study sample using Fisher's exact test and compared them with the previous findings using the Mantel/Haenszel Chi-square test for stratified data. All statistical analyses were performed using STATA ${ }^{\text {TM }} 9.1$ (StataCorp 2005) (stata.com/support/faqs/res/cite.html).

Ethics - The use and handling of animals in this study was approved by the Bioethical Committee of the Faculty of Veterinary Science, University of Chile. 


\section{RESULTS}

We captured a total of 360 triatomines, corresponding to 97 T. infestans and 263 M. spinolai. In total, 34 T. infestans were captured in February 2008, four in November 2008, 50 in January 2009 and nine in May 2009. No adult $T$. infestans was captured; only nymphal individuals were found. Figs 3 and 4 show the population structure observed in each field expedition for both triatomine species.

The average distance from $T$. infestans capture locations to human dwellings was approximately $600 \mathrm{~m}$ (range 159-1053 m). The thematic map in Fig. 1 shows

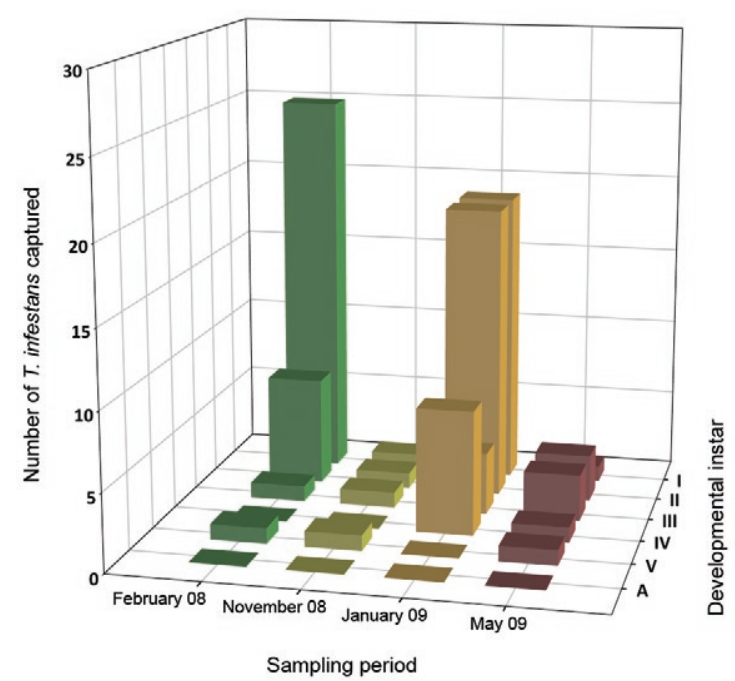

Fig. 3: observed population structure of sylvatic Triatoma infestans captured in the locality of Sahondé, commune of Putaendo, Valparaíso region, Chile, by sampling period.

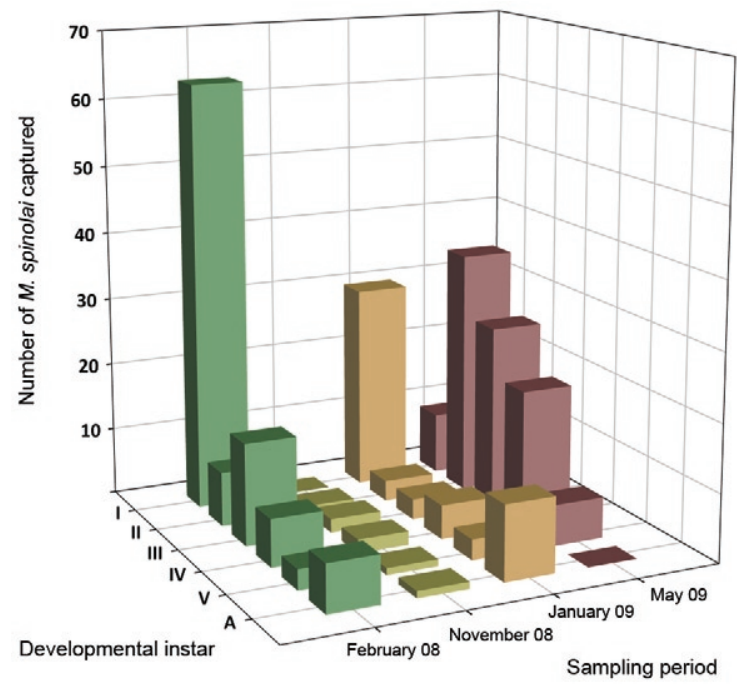

Fig. 4: observed population structure of sylvatic Mepraia spinolai captured in the locality of Sahondé, commune of Putaendo, Valparaíso region, Chile, by sampling period. green diamonds for the georeferenced points where $T$. infestans was caught in the rock piles and red diamonds for M. spinolai. Most of the infested points of the rock piles were covered by hawthorn spiny branches (Fig. 2). Sites with dry mud in the spaces between the stones were always negative for triatomines.

The number of positive traps per bait for T. infestans, M. spinolai and both species together is shown in Table II by sampling period, along with the minimum and maximum counts of insects per positive trap.

We confirmed the taxonomic status of T. infestans in the individuals that were analyzed using DNA-based tests (data not shown).

A total of 52 of the 97 captured individuals of T. infestans were analyzed using PCR to evaluate T. cruzi infection. This subsample comprised 32 individuals captured in February 2008 and 20 from January 2009. Of these individuals, 19 (36.54\%) had positive reactions, indicating infection with $T$. cruzi. Table III shows the proportion of infection from both summer samplings according to nymphal instar analyzed.

\section{DISCUSSION}

Our study is the second report of a sylvatic location of $T$. infestans in Central Chile. The first report was located in the metropolitan region, about $113 \mathrm{~km} \mathrm{SSW}$ from this focus, where T. infestans was found inhabiting bromeliads located in a mountain range (Bacigalupo et al. 2006). We have sampled several other areas in central Chile: Til-Til in the metropolitan region, Petorca and Los Andes in the Valparaíso region and Illapel, Salamanca and Monte Patria in the Coquimbo region, screening for wild T. infestans without success (BA Bacigalupo et al., unpublished observations). In all of these areas, there were places in which $M$. spinolai was found using the same methodology implemented here. Only a few previous reports have described $T$. infestans coexisting with M. spinolai within human dwellings or in their immediate vicinity (Schenone et al. 1980), but this is the first study that has detected both $T$. infestans and $M$. spinolai living in sympatry in wild habitats. Previous laboratory studies have reported that these two species show a general similarity in their temperature selection patterns, suggesting a preference for similar substrates (Canals et al. 1997), which was confirmed here by finding both species occupying the same rock piles.

Wild populations of $T$. infestans in Chile may be a consequence of a geographic expansion of the primitive wild population from the Andean mesothermic valleys of Bolivia (Noireau et al. 2005) or they may have been dispersed by the transport and distribution of maize throughout distant provinces of the Inca empire (Cortez et al. 2010). These wild populations could also be derivatives of domestic insects recolonizing wild habitats (Noireau 2009). Another explanation for the presence of $T$. infestans in central Chile is passive transport from Argentina, a country that has already proven the existence of wild foci of this species (Mazza \& Schreiber 1938, Mazza 1943, Ceballos et al. 2009), as previously suggested by wing morphometric analysis (Cristi 2001). The notion of sylvatic sites should be interpreted as geo- 
TABLE II

Number and percentage of positive traps that captured each triatomine species and minimum and maximum number of insects captured per trap, by sampling period

\begin{tabular}{|c|c|c|c|c|c|c|c|c|c|c|c|c|c|c|c|c|c|}
\hline \multirow[b]{2}{*}{ Bait type } & \multirow{2}{*}{$\begin{array}{l}\text { Triatomine sp. } \\
\text { captured }\end{array}$} & \multicolumn{4}{|c|}{ February 2008} & \multicolumn{4}{|c|}{ November 2008} & \multicolumn{4}{|c|}{ January 2009} & \multicolumn{4}{|c|}{ May 2009} \\
\hline & & $\mathrm{n}^{a}$ & $\%$ & $\operatorname{Min}^{b}$ & $\operatorname{Max}^{c}$ & $\mathrm{n}^{a}$ & $\%$ & $\operatorname{Min}^{b}$ & $\operatorname{Max}^{c}$ & $\mathrm{n}^{a}$ & $\%$ & $\operatorname{Min}^{b}$ & $\operatorname{Max}^{c}$ & $\mathrm{n}^{a}$ & $\%$ & $\operatorname{Min}^{b}$ & $\operatorname{Max}^{c}$ \\
\hline \multirow[t]{3}{*}{ Dry ice } & Triatoma infestans ${ }^{d}$ & - & - & - & - & 5 & 40 & 1 & 1 & - & - & - & - & 19 & 21 & 1 & 2 \\
\hline & Mepraia spinolai $^{d}$ & - & - & - & - & & 60 & 1 & 2 & - & - & - & - & & 73.7 & 1 & 11 \\
\hline & Both species ${ }^{e}$ & - & - & - & - & & 0 & - & - & - & - & - & - & & 5.3 & 13 & 13 \\
\hline \multirow[t]{3}{*}{ Yeast } & T. infestans ${ }^{d}$ & 17 & 29.4 & 1 & 2 & - & - & - & - & 20 & 60 & 1 & 3 & - & - & - & - \\
\hline & M. spinolai ${ }^{d}$ & & 64.7 & 1 & 7 & - & - & - & - & & 40 & 1 & 9 & - & - & - & - \\
\hline & Both species ${ }^{e}$ & & 5.9 & 2 & 2 & - & - & - & - & & 0 & - & - & - & - & - & - \\
\hline \multirow[t]{3}{*}{ Mouse } & T. infestans ${ }^{d}$ & 38 & 10.5 & 1 & 6 & 2 & 50 & 2 & 2 & 19 & 31.6 & 1 & 24 & - & 15.8 & 1 & 1 \\
\hline & M. spinolai ${ }^{d}$ & & 76.3 & 1 & 12 & & 50 & 2 & 2 & & 63.1 & 1 & 8 & 19 & 84.2 & 1 & 9 \\
\hline & Both species ${ }^{e}$ & & 13.2 & 2 & 8 & & 0 & - & - & & 5.3 & 8 & 8 & - & 0 & - & - \\
\hline
\end{tabular}

$a$ : number of traps from each bait that captured triatomines; $b$ : minimum count of insects per positive trap; $c$ : maximum count of insects per positive trap; $d$ : triatomine species captured alone (not mixed); $e$ : count of insect from both species together per positive trap.

TABLE III

Number of analyzed individuals by instar and percentage of infected Triatoma infestans in two summer capturing periods from the locality of Sahondé, commune of Putaendo, Valparaíso region, Chile

\begin{tabular}{lcccccc}
\hline & \multicolumn{2}{c}{$\begin{array}{c}\text { February } \\
2008\end{array}$} & \multicolumn{2}{c}{$\begin{array}{c}\text { January } \\
2009\end{array}$} & \multicolumn{2}{c}{$\begin{array}{c}\text { Both } \\
\text { periods }\end{array}$} \\
\cline { 2 - 7 } $\begin{array}{l}\text { Developmental } \\
\text { stage }\end{array}$ & $\mathrm{n}$ & $\%$ & $\mathrm{n}$ & $\%$ & $\mathrm{n}$ & $\%$ \\
\hline I & 23 & 17.39 & 5 & 100 & 28 & 32.14 \\
II & 7 & 42.86 & 10 & 30 & 17 & 35.29 \\
III & 1 & 100 & 2 & 50 & 3 & 66.67 \\
IV & 0 & - & 3 & 33.33 & 3 & 33.33 \\
V & 1 & 100 & 0 & - & 1 & 100 \\
\hline Total & 32 & 28.13 & 20 & 50 & 52 & 36.54 \\
\hline
\end{tabular}

graphically restricted records, such as those registered in our study, which probably represent point occurrence data from more widespread populations (Noireau 2009). T. infestans was found in Putaendo inhabiting rock-piles (rupicolous), differing from our previous report in the metropolitan region, where they inhabited terrestrial bromeliads (Bacigalupo et al. 2006). This finding is consistent with other studies showing the remarkable behav- ioral plasticity of $T$. infestans, unlike other triatomine species, which show a marked preference for a particular type of habitat (Noireau et al. 2005, Noireau 2009).

All of the bait types used captured both species of triatomines, as shown in Table II. Because the baited system is likely to attract and capture starved bugs, the observed stage structure of both populations (Figs 3, 4) may be biased (Noireau et al. 2000). We observed differing counts of T. infestans between seasons. Differences in host availability and feeding frequency by seasonality (López et al. 1999, Ceballos et al. 2005) and instar (Ceballos et al. 2005), fecundity and mortality seasonality (Canals et al. 1991) and different capacities to move (Vazquez-Prokopec et al. 2006) along with their behavior to enter into an induced diapause when the environmental conditions are adverse (Canals et al. 1992) may explain our results.

In this study, triatomine foci were mainly associated with rodents and the marsupial Thylamys elegans that were captured in the immediate vicinity of the rock piles (unpublished observations) and also with rabbits that nested in caves underneath the rock piles. This marsupial species has shown seasonal and inter-year variability (Lima et al. 2001) and Phyllotis darwini population growth rates exhibit a clear seasonal structure (Lima et al. 2002a). There are many studies regarding the influence that El Niño Southern Oscillation climatic phenomena has on the population dynamics of many rodents in Chile (Lima et al. 2002b); therefore, these phenomena may have some influence on triatomine population dy- 
namics as well: indirectly by means of their hosts or directly by affecting environmental variables. The synanthropic species of the Rattus genus might pose a higher risk to the human population because they could become infected in the sylvatic environment and then return to the domestic habitat (Lobos et al. 2005), where they could become reservoirs to the domestic vectors.

The study of Canals et al. (1991) on T. infestans under stable laboratory conditions observed that the lowest fecundity occurred during April (autumn) and the maximum occurred in October-November (spring), which could explain the low number of immature stages (I-III instars) during November and May and the higher numbers during summer (Fig. 3). Studies in sylvatic $M$. spinolai from an area of the metropolitan region have shown seasonal fluctuations in the proportions of individuals of each instar, with a predominance of immature stages (instars I-III) between January-May (summerautumn) before attaining a certain equilibrium between immature and mature instars (instars IV-V and adults) between September-December (Canals et al. 1998), which is consistent with our results (Fig. 4).

Canals et al. (1998) have also shown that M. spinolai shows large density differences between sites, e.g., $200 \mathrm{bugs} / \mathrm{m}^{2}$ and $20 \mathrm{bugs} / \mathrm{m}^{2}$ in two places separated by a distance of less than $10 \mathrm{~m}$; therefore, if T. infestans is similarly patchily distributed, it is possible that some of the low capture rates are due to the misplacement of the trap far from a focus of higher density.

The lack of adult forms in Putaendo may be evidence of the slow development of $T$. infestans living outdoors. However, it may reflect rapid flight dispersal once they molt to the last instar (Lehane \& Schofield 1982), aided by high summer temperatures (Lehane et al. 1992, Gurevitz et al. 2006).

The evaluation of the infectious state of $T$. infestans with $T$. cruzi is performed using microscopic examination of their defecations and/or molecular detection of its kDNA or nuclear DNA (Flores et al. 1984, Venegas et al. 1984, Villarroel et al. 1984, Russomando et al. 1996, Braz et al. 2007, Pizarro et al. 2007). In our investigation, the levels of infection detected $(36.54 \%)$ were similar $\left(X^{2}=0.1922 ; p=0.661\right)$ to the overall infection found previously in the metropolitan region $(40.91 \%)$ in 44 specimens analyzed by Bacigalupo et al. (2006). We found no difference between the proportion of positivity for $T$. cruzi between the different developmental instars of T. infestans within Putaendo (Fisher's exact test $\mathrm{p}=$ 0.605). The Mantel/Haenszel Chi-squared test for stratified data also showed no differences when the positivity in each nymphal instar was compared between Putaendo and the previous data of the metropolitan region (Bacigalupo et al. 2006) $\left(\mathrm{X}^{2} \mathrm{H}-\mathrm{M}=0.366 ; \mathrm{p}=0.55\right)$; however, results reported in other wild $T$. infestans foci in South America are highly variable. For example, infection indexes in endemic areas of Bolivia vary from $2.5 \%$ in the Chaco to $60 \%$ in the Andes (Noireau et al. 2000, Cortez et al. 2006, 2007). This wide range of infection was suggested to be the result of different sources of their blood meal hosts, with the lower levels resulting from feeding mainly on birds - which are not susceptible to
T. cruzi - and the higher levels resulting from feeding mostly on mammals' blood (Noireau et al. 2000, Cortez et al. 2006). In the first focus reported in the Argentine Chaco, all of the $14 T$. infestans captured in trees were negative for $T$. cruzi using microscopic examination, probably because they were mainly associated with birds (Ceballos et al. 2009).

Our current and previous studies (Bacigalupo et al. 2006) showed nymphal instars with similar levels of infection between them. Nymphs can get infected at an early age by feeding on a parasitized mammal host soon after their eclosion or by active cannibalism on or eating excrement of older infected instars (Schaub 1988). This emphasizes the importance of studying all triatomine instars (Botto-Mahan et al. 2005) as well as the presence of reservoirs to understand the local transmission cycle of T. cruzi. Younger instars disperse only by walking small distances; therefore, they would have a lower impact on parasite dispersion, unlike the flying adults, which can scatter farther from their original focus. Although $T$. infestans is not considered a good flyer, it can disperse over distances of at least $1.5 \mathrm{~km}$ (Schweigmann et al. 1988). In the absence of domestic colonies, wild foci may act as sources of individuals that colonize previously treated domestic settings, following 'sourcesink' dynamics (Dias 1996). For example, we detected a nearby building that constantly reported adults during spring and summer but was $415 \mathrm{~m}$ away from the nearest detected capture of $T$. infestans. The settlement was a psychiatric hospital and we speculate that people are constantly exposed to the vector, which would be attracted by the artificial lights on the building (Minoli \& Lazzari 2006), causing high risk of contracting the infection to their inhabitants.

The concept of an absence of wild vector populations, which would preclude the recolonization of treated areas by insects coming from wild sites, was a pivotal argument used for launching large-scale control campaigns against this particular species (Silveira 2002, Noireau et al. 2005). Recent reports have provided evidence that wild populations of T. infestans are much more widespread throughout the Southern Cone of South America, showing the need for further research on this important and neglected issue, particularly on the role that sylvatic populations play in the process of recolonization of insecticide-treated residences (Noireau et al. 2005). $T$. infestans wild foci limit the projected elimination of the species outside Bolivia that has been proposed by INCOSUR (Silveira 2002).

The main epidemiological risk of wild triatomines resides in their ability to transmit $T$. cruzi to people. The change from an elimination strategy to one of continuous selective intervention implicitly carries the acceptance that occasional accidental transmission might occur due to adventitious sylvatic vectors entering houses (Schofield et al. 2006). These cases must be promptly diagnosed and treated, reinforcing the local surveillance and sanitary programs as well as community education and organization for proper knowledge about Chagas disease and its vectors, enabling the local community to inform local authorities about recent infestations within 
their dwellings or accidental transmission of the disease to ensure appropriate and on-time treatment (Schofield et al. 2006). In Chile, vector control programs should be maintained and active searches for triatomines in wild habitats should be included in governmental and academic plans to detect areas with a high risk of transmission due to possible domestication processes and accidental vectorial transmission. Education to prevent Chagas disease vectorial transmission should be reinforced by adding information about triatomines' sylvatic habitat, teaching people to avoid resting near structures that may harbor kissing bugs such as bromeliads, caves, an accumulation of stones or rock crevices and to be vigilant when working in crop fields or stone quarries or visiting or travelling in the endemic area. New vector control strategies must be tested, for instance, in regions were $T$. infestans is only found as adult forms inside houses. The long-lasting impregnated curtains or mosquito mesh strategy proposed by Ferral et al. (2010) for non-domiciled Triatoma dimidiata might be a good alternative. The susceptibility of Chilean triatomines to pathogens should be tested to provide a biological mechanism of control that specifically targets the species of interest, maybe even in its sylvatic habitat.

Our study, together with other studies in Chile on triatomine vector species and their T. cruzi infection (BottoMahan et al. 2005, 2008, Bacigalupo et al. 2006), shows that vectorial transmission of Chagas disease might still occur in the country if it becomes a neglected disease or if it is forgotten, not funded and/or not controlled. The current control strategies should be re-designed to incorporate the new findings of wild foci of T. infestans, along with the absence of domestic colonies of this species and the reiterative invasions that adults perform into the dwellings to redirect economical efforts to adequate sanitary and environmentally friendly measures in this case, instead of applying insecticides to the whole dwelling as the final solution for adult-infested houses.

\section{ACKNOWLEDGEMENTS}

To Carlos Landaeta, Cristina Krestchmer, Natalia Lártiga, Ismael Varela, Ángel Rain, Ministerio de Salud Chile, SEREMI de Salud Región de Valparaíso, Hospital Psiquiátrico de Putaendo, and to Hugo Sierra G. Yadeeh Sawyer, to kindly review the draft paper.

\section{REFERENCES}

Bacigalupo A, Segura JA, García A, Hidalgo J, Galuppo S, Cattan PE 2006. Primer hallazgo de vectores de la enfermedad de Chagas asociados a matorrales silvestres en la Región Metropolitana, Chile. Rev Med Chil 134: 1230-1236.

Barretto MP, Siqueira AF, Côrrea FMA 1963. Estudos sobre reservatórios e vetores silvestres do Trypanosoma cruzi. I. Encontro do Triatoma infestans em ecótopos silvestres. Rev Inst Med Trop Sao Paulo 5: 289-293.

Beard CB, Cordon-Rosales C, Durvasula RV 2002. Bacterial symbionts of the triatominae and their potential use in control of Chagas disease transmission. Annu Rev Entomol 47: 123-141.

Botto-Mahan C, Cattan PE, Canals M 2002. Field tests of carbon dioxide and conspecifics as baits for Mepraia spinolai, wild vector of Chagas disease. Acta Trop 82: 377-380.
Botto-Mahan C, Ortiz S, Rozas M, Cattan PE, Solari A 2005. DNA evidence of Trypanosoma cruzi in the Chilean wild vector $\mathrm{Me}$ praia spinolai (Hemiptera: Reduviidae). Mem Inst Oswaldo Cruz 100: 237-239.

Botto-Mahan C, Sepúlveda M, Vidal M, Acuña-Retamar M, Ortiz S, Solari A 2008. Trypanosoma cruzi infection in the sylvatic kissing bug Mepraia gajardoi from the Chilean southern Pacific Ocean coast. Acta Trop 105: 166-169.

Braz LM, Raiz R Jr, Neto A, Alárcon RS, Gakyia E, Okay TS 2007. The detection of Trypanosoma cruzi in Triatoma infestans: comparison of a PCR-based assay with microscopical examination. Ann Trop Med Parasitol 101: 461-465.

Brewer M, Garay M, Gorla D, Murua F, Favot R 1981. Caracterización de los estadios ninfales del género Triatoma Laporte 1833. I. Triatoma infestans Klug, 1834 (Hemiptera: Reduviidae). Rev Soc Entomol Argent 40: 91-102.

Canals M, Cattan PE, Ehrenfeld M, Torres P 1992. Poblaciones experimentales de Triatoma infestans: efectos de condiciones ambientales variables. Parasitol dia 16: 72-77.

Canals M, Cattan PE, Solis R, Valderas J 1991. Biología de poblaciones de Triatoma infestans: fluctuaciones de la fecundidad y la mortalidad. Rev Med Chil 119: 979-983.

Canals M, Ehrenfeld M, Solis R, Cruzat R, Pinochet A, Tapia C, Cattan PE 1998. Biología comparada de Mepraia spinolai en condiciones de laboratorio y terreno: cinco años de estudio. Parasitol dia 22: 72-78.

Canals M, Solis R, Valderas J, Ehrenfeld M, Cattan PE 1997. Preliminary studies on temperature selection and activity cycles of Triatoma infestans and T. spinolai (Heteroptera: Reduviidae), Chilean vectors of Chagas' disease. J Med Entomol 34: 11-17.

Ceballos LA, Piccinali RV, Berkunsky I, Kitron U, Gürtler RE 2009. First finding of melanic sylvatic Triatoma infestans (Hemiptera: Reduviidae) colonies in the Argentine Chaco. J Med Entomol 46: 1195-1202.

Ceballos LA, Vasquez-Prokopec GM, Cecere MC, Marcet PL, Gürtler RE 2005. Feeding rates, nutritional status and flight dispersal potential of peridomestic populations of Triatoma infestans in rural northwestern Argentina. Acta Trop 95: 149-159.

Cortez MR, Emperaire L, Piccinali RV, Gürtler RE, Torrico F, Jansen AM, Noireau F 2007. Sylvatic Triatoma infestans (Reduviidae: Triatominae) in the Andean valleys of Bolivia. Acta Trop 102: 47-54.

Cortez MR, Monteiro FA, Noireau F 2010. New insights on the spread of Triatoma infestans from Bolivia - implications for Chagas disease emergence in the Southern Cone. Infect Genet Evol 10: 350-353.

Cortez MR, Pinho AP, Cuervo P, Alfaro F, Solano M, Xavier SC, D'Andrea PS, Fernandes O, Torrico F, Noireau F, Jansen AM 2006. Trypanosoma cruzi (Kinetoplastida Trypanosomatidae): ecology of the transmission cycle in the wild environment of the Andean valley of Cochabamba, Bolivia. Exp Parasitol 114: 305-313.

Cristi D 2001. Caracterización fenotípica por medio de morfometría geométrica de las alas de Triatoma infestans en el área endémica de la enfermedad de Chagas en Chile, DMV Thesis, Universidad de Chile, Santiago, $115 \mathrm{pp}$.

Dias P 1996. Sources and sinks in population biology. Trends Ecol Evol 11: 326-330.

Drummond AJ, Rambaut A 2007. BEAST: Bayesian evolutionary analysis by sampling trees. BMC Evol Biol 7: 214. 
ESRI 1999-2006. ArcGISTM [GIS Software]. Version 9.2, Redlands, CA: Environmental Systems Research Institute, Inc.

Ferral J, Chavez-Nuñez L, Euan-Garcia M, Ramirez-Sierra MJ, Najera-Vazquez MR, Dumonteil E 2010. Comparative field trial of alternative vector control strategies for non-domiciliated Triatoma dimidiata. Am J Trop Med Hyg 82: 60-66.

Fitzpatrick S, Feliciangeli MD, Sanchez-Martin MJ, Monteiro FA, Miles MA 2008. Molecular genetics reveal that silvatic Rhodnius prolixus do colonise rural houses. PLoS Negl Trop Dis 2: e210.

Flores B, Hernández G, Lepe A, Contreras MC, Sandoval L, Villarroel F, Rojas A, González O, Schenone H 1984. Epidemiología de la enfermedad de Chagas en Chile. Sectores rurales. Infestación triatomídea domiciliaria e infección por Trypanosoma cruzi del vector y de mamíferos domésticos de la V Región, 1983. Bol Chil Parasitol 39: 62-65.

Frias D, Henry A, González CR 1998. Mepraia gajardoi: a new species of Triatomidae (Hemiptera: Reduviidae) from Chile and its comparison with Mepraia spinolai. Rev Chil Hist Nat 71: 177-188.

Frias D, Martinez H, Wallace A 1987. Algunos aspectos taxonómicos de Triatoma spinolai Porter (Hemiptera: Triatominae). Acta Entomol Chil 14: 115-169.

Gajardo R 1995. La vegetación natural de Chile: clasificación y distribución geográfica, 2nd ed., Universitaria, Santiago, 165 pp.

Galuppo S, Bacigalupo A, García A, Ortiz S, Coronado X, Cattan PE, Solari A 2009. Predominance of Trypanosoma cruzi genotypes in two reservoirs infected by sylvatic Triatoma infestans of an endemic area of Chile. Acta Trop 111: 90-93.

Guhl F, Pinto N, Aguilera G 2009. Sylvatic triatominae: a new challenge in vector control transmission. Mem Inst Oswaldo Cruz 104 (Suppl. I): 71-75.

Gurevitz JM, Ceballos LA, Kitron U, Gürtler RE 2006. Flight initiation of Triatoma infestans (Hemiptera: Reduviidae) under natural climatic conditions. J Med Entomol 43: 143-150.

Gürtler RE 2009. Sustainability of vector control strategies in the Gran Chaco region: current challenges and possible approaches. Mem Inst Oswaldo Cruz 104 (Suppl. I): 52-59.

Lehane MJ, McEwen PK, Whitaker CJ, Schofield CJ 1992. The role of temperature and nutritional status in flight initiation by Triatoma infestans. Acta Trop 52: 27-38.

Lehane MJ, Schofield CJ 1982. Flight initiation in Triatoma infestans (Klug) (Hemiptera: Reduviidae). Bull Entomol Res 72: 497-510.

Lent H, Jurberg J, Galvão C 1994. Revalidação do gênero Mepraia, Mazza, Gajardo \& Jörg, 1940 (Hemiptera: Reduviidae: Triatominae). Mem Inst Oswaldo Cruz 89: 347-352.

Lent H, Wygodzinsky P 1979. Revision of the Triatominae (Hemiptera: Reduviidae) and their significance as vectors of Chagas disease. Bull Am Mus Nat Hist 163: 123-520.

Lima M, Stenseth NC, Jaksic FM 2002a. Population dynamics of a South American rodent: seasonal structure interacting with climate, density dependence and predator effects. Proc Biol Sci 269: 2579-2586.

Lima M, Stenseth NC, Jaksic FM 2002b. Food web structure and climate effects on the dynamics of small mammals and owls in semi-arid Chile. Ecol Lett 5: 273-284.

Lima M, Stenseth NC, Yoccoz NG, Jaksic FM 2001. Demography and population dynamics of the mouse opossum (Thylamys elegans) in semi-arid Chile: seasonality, feedback structure and climate. ProcBiol Sci 268: 2053-2064.
Lobos G, Ferres M, Palma RE 2005. Presencia de los géneros invasores Mus y Rattus en áreas naturales de Chile: un riesgo ambiental y epidemiológico. Rev Chil Hist Nat 78: 113-124.

López A, Crocco L, Morales G, Catalá S 1999. Feeding frequency and nutritional status of peridomestic populations of Triatoma infestans from Argentina. Acta Trop 73: 275-281.

Lorca M, García A, Bahamonde MI, Fritz A, Tassara R 2001. Certificación serológica de la interrupción de la transmisión vectorial de la enfermedad de Chagas en Chile. Rev Med Chil 129: 264-269.

Lorenzo MG, Reisenman CE, Lazzari CR 1998. Triatoma infestans can be captured under natural climatic conditions using yeastbaited traps. Acta Trop 70: 277-284.

Mazza S 1943. Comprobaciones de Triatoma platensis, Eutriatoma oswaldoi, Panstrongylus seai y Psammolestes coreodes en la Provincia de Santiago del Estero, todos ellos sin infestación y de Eutriatoma sordida con infestación por $S$. cruzi. Otros datos sobre infestación esquizotripanósica natural silvestre de Triatoma infestans. Prensa Med Arg 30: 1-23.

Mazza S, Schreiber F 1938. Hallazgos en el Departamento General Obligado, Santa Fe, de otra especie de mustélido naturalmente infectado con Schizotrypanum cruzi, de Triatoma infestans infestados en nidos de comadrejas; de Triatoma platensis en nidos de psitácidos y Psammolestes coreodes sin infestación en nidos de dendrocoláptidos. MEPRA Publicación 34: 17-35.

Minoli SA, Lazzari CR 2006. Take-off activity and orientation of triatomines (Heteroptera: Reduviidae) in relation to the presence of artificial lights. Acta Trop 97: 324-330.

Moncayo A, Silveira AC 2009. Current epidemiological trends for Chagas disease in Latin America and future challenges in epidemiology, surveillance and health policy. Mem Inst Oswaldo Cruz 104 (Suppl. I): 17-30.

Neghme RA 1982. La Tripanosomiasis en América. Creces 3: 23-28.

Noireau F 2009. Wild Triatoma infestans, a potential threat that needs to be monitored. Mem Inst Oswaldo Cruz 104 (Suppl. I): 60-64.

Noireau F, Abad-Franch F, Valente S, Dias-Lima A, Lopes C, Cunha V, Valente VC, Palomeque FS, Carvalho-Pinto CJ, Sherlock I, Aguilar M, Steindel M, Grisard EC, Jurberg J 2002. Trapping Triatominae in silvatic habitats. Mem Inst Oswaldo Cruz 97: 61-63.

Noireau F, Cortez MG, Monteiro F, Jansen AM, Torrico F 2005. Can wild Triatoma infestans foci in Bolivia jeopardize Chagas disease control efforts? Trends Parasitol 21: 7-10.

Noireau F, Flores R, Gutierrez T, Abad-Franch F, Flores E, Vargas F 2000. Natural ecotopes of Triatoma infestans dark morph and other sylvatic triatomines in the Bolivian Chaco. Trans $R$ Soc Trop Med Hyg 94: 23-27.

Noireau F, Flores R, Gutierrez T, Dujardin JP 1997. Detection of sylvatic dark morphs of Triatoma infestans in the Bolivian Chaco. Mem Inst Oswaldo Cruz 92: 583-584.

Noireau F, Flores R, Vargas F 1999. Trapping sylvatic Triatominae (Reduviidae) in hollow trees. Trans $R$ Soc Trop Med Hyg 93: 13-14.

Novoa R, Villaseca S, Del Canto P, Rouanet J, Sierra C, Del Pozo A 1989. Mapa agroclimático de Chile, Instituto de Investigaciones Agropecuarias INIA, Ministerio de Agricultura, Santiago, 221 pp.

Pizarro JC, Lucero DE, Stevens L 2007. PCR reveals significantly higher rates of Trypanosoma cruzi infection than microscopy in the Chagas vector, Triatoma infestans: high rates found in Chuquisaca, Bolivia. BMC Infect Dis 7: 66. 
Russomando G, Rojas de Arias A, Almiron M, Figueredo A, Ferreira ME, Morita K 1996. Trypanosoma cruzi: polymerase chain reaction-based detection in dried feces of Triatoma infestans. Exp Parasitol 83: 62-66.

Schaub GA 1988. Direct transmission of Trypanosoma cruzi between vectors of Chagas' disease. Acta Trop 45: 11-19.

Schenone H, Villarroel F, Rojas A, Alfaro E 1980. Factores biológicos y ecológicos en la epidemiología de la enfermedad de Chagas en Chile. Bol Chil Parasitol 35: 42-54.

Schmunis GA 2000. A tripanossomiase Americana e seu impacto na saúde pública das Américas. In Z Brener, Z Andrade, M BarralNeto, Trypanosoma cruzi e doença de Chagas, 2nd ed., Guanabara Koogan, Rio de Janeiro, p. 1-15.

Schofield CJ, Jannin J, Salvatella R 2006. The future of Chagas disease control. Trends Parasitol 22: 583-588.

Schweigmann N, Vallvé S, Muscio O, Ghillini M, Alberti A, Wisnivesky-Colli C 1988. Dispersal flight by Triatoma infestans in an arid area of Argentina. Med Vet Entomol 2: 401-404.

Silveira AC 2002. O controle da doença de Chagas nos países do Cone Sulda América. História de umainiciativainternacional 1991/2001. In AC Silveira, A Rojas de Arias, E Segura, G Guillén, G Russomando, H Schenone, JCP Dias, J Valdes, M Lorca, R Salvatella, El control de la enfermedad de Chagas en los paises del Cono Sur de América: historia de una iniciativa internacional, 1991/2001, Facultad de Medicina do Triangulo Mineiro, Uberaba, p. 15-43.

Spinola M 1852. Hemipteros. In C Gay (ed.), Historia física y politica de Chile, Vol. VII, Zoologia, Maulde y Renou, Paris, p. 133-320.
Torrico RA 1946. Hallazgo de Eratyrus mucronatus, infestación natural de "vinchucas" de cerro y Eutriatoma sordida en Cochabamba. An Lab Central Cochabamba 1: 19-23.

Vazquez-Prokopec GM, Ceballos LA, Marcet PL, Cecere MC, Cardinal MV, Kitron U, Gürtler RE 2006. Seasonal variations in active dispersal of natural populations of Triatoma infestans in rural north-western Argentina. Med Vet Entomol 20: 273-279.

Velasquez CJ, González G 1959. Aspectos de la enfermedad de Chagas en Paraguay. Rev Goiana Med 5: 357-373.

Venegas L, Rojas A, Villarroel F, Contreras MC, Sandoval L, Schenone H 1984. Epidemiología de la enfermedad de Chagas en Chile. Sectores rurales. Infestación triatomídea domiciliaria e infección por Trypanosoma cruzi del vector y mamíferos domésticos de la VI Región del Libertador General Bernardo O’Higgins, 1983. Bol Chil Parasitol 39: 69-72.

Villarroel F, Rojas A, Contreras MC, Schenone H 1984. Epidemiología de la enfermedad de Chagas en Chile. Sectores rurales. Infestación triatomídea domiciliaria e infección por Trypanosoma cruzi de los vectores y mamíferos domésticos de la Región Metropolitana, 1982-1984. Bol Chil Parasitol 39: 65-68.

Wincker P, Bosseno MF, Britto C, Yaksic N, Cardoso MA, Morel CM, Brenière SF 1994. High correlation between Chagas' disease serology and PCR-based detection of Trypanosoma cruzi kinetoplast DNA in Bolivian children living in an endemic area. FEMS Microbiol Lett 124: 419-423.

World Bank 1993. World Development Report 1993: investing in health, Oxford University Press, New York, 329 pp. 